\title{
Upgrading greenhouse gases (methane and carbon dioxide) into syngas using nickel-based catalysts
}

\author{
Bruna Rego de Vasconcelos*, Doan Pham Minh, Nathalie Lyczko, Thanh Son Phan, \\ Patrick Sharrock, Ange Nzihou
}

Université de Toulouse, Mines Albi, UMR CNRS 5302, Centre RAPSODEE, Campus Jarlard, F-81013 Albi cedex 09, France

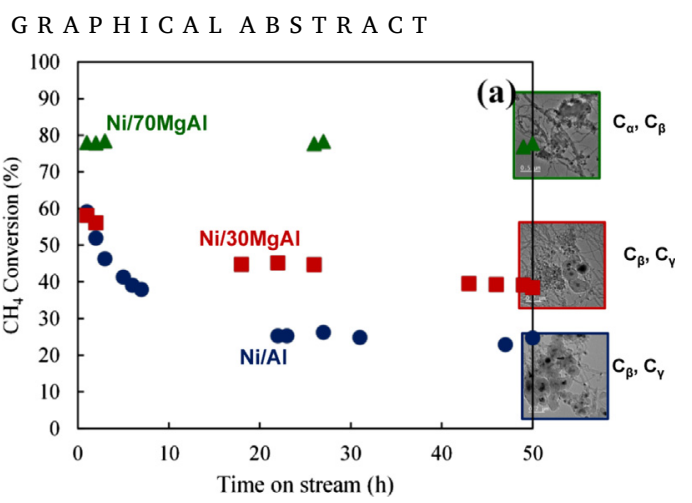

\section{A B S T R A C T}

In this work, $\mathrm{Mg}$-doped $\mathrm{Al}_{2} \mathrm{O}_{3}$ supports were used for the preparation of $\mathrm{Ni}$ catalysts, which were then tested in dry reforming of methane reaction (DRM) for syngas production. The influence of $\mathrm{MgO}$ content $(0-70 \mathrm{wt} \%)$ on the basicity of the catalysts as well as on the formation of a NiO-MgO solid solution was investigated and linked to the catalytic performance of the catalysts. The catalyst containing high amount of $\mathrm{Mg}(\mathrm{Ni} / 70 \mathrm{MgAl})$ showed the best performance with negligible deactivation rate over $50 \mathrm{~h}$ of time on stream (TOS). The presence of strong basic sites in this catalyst was important to adsorb carbon dioxide $\left(\mathrm{CO}_{2}\right)$, to gasify the coke deposit and to increase the syngas production. Also, the presence of a NiO-MgO solid solution led to strong metal-support interaction, which limited the sintering of nickel particles. The quantification of the water formed during the reaction showed that its formation was crucial for the elimination of the coke deposits as well as to increase the syngas production.

\section{Keywords:}

Greenhouse gases

Catalyst deactivation

Basicity

Solid solution

Carbon gasification

\section{Introduction}

$\mathrm{CO}_{2}$ reforming of methane, also known as dry reforming of methane, (Eq. (1)) has received great attention in the past few years since it converts $\mathrm{CO}_{2}$ and $\mathrm{CH}_{4}$, the two main greenhouse gases, into syngas, which can be later used for the production of energy, fuels and added- value chemicals, such as dimethyl ether, formaldehyde, olefins, etc $[1,2]$.

Dry reforming of methane (DRM):

$\mathrm{CH}_{4}+\mathrm{CO}_{2} \leftrightarrow 2 \mathrm{H}_{2}+2 \mathrm{CO}$

$\Delta H^{\circ}{ }_{298}=247 \mathrm{~kJ} / \mathrm{mol} ; \Delta G^{\circ}=61770-67.32 \mathrm{~T}$

\footnotetext{
Corresponding author at: Ecole des Mines d'Albi-Carmaux, 81000 Albi, France.

E-mail address: bregodev@mines-albi.fr (B. Rego de Vasconcelos).
} 


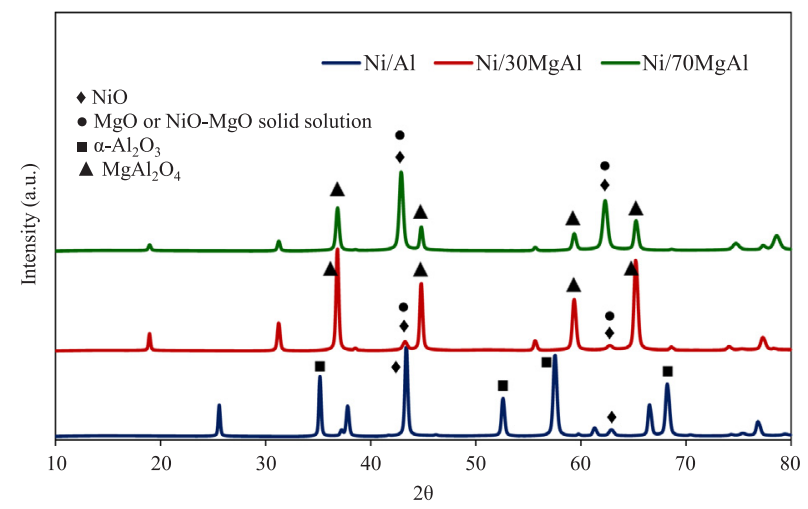

Fig. 1. XRD patterns of the fresh catalysts.

Table 1

XRD characterization of the $70 \mathrm{MgAl}$ support and $\mathrm{Ni} / 70 \mathrm{MgAl}$ catalyst.

\begin{tabular}{lcccccc}
\hline Sample & \multicolumn{3}{c}{$\begin{array}{c}\mathrm{MgO} \text { or solid solution XRD } \\
\text { parameters }\end{array}$} & $\begin{array}{c}\text { Possible } \\
\text { match }\end{array}$ & $\begin{array}{c}\mathrm{MgO} \\
(\mathrm{wt} \%)\end{array}$ & $\mathrm{R}_{\mathrm{Bragg}}$ \\
\cline { 2 - 5 } & $2 \theta$ & $\begin{array}{c}\text { Cell } \\
\mathrm{a}=\mathrm{b}=\mathrm{c}(\mathrm{A})\end{array}$ & $\begin{array}{c}\mathrm{d}^{*} \\
(\mathrm{~nm})\end{array}$ & & & \\
\hline $70 \mathrm{MgAl}$ & 42.88 & 4.214 & 12.8 & $\mathrm{MgO}$ & 59.7 & 1.81 \\
$\mathrm{Ni} / 70 \mathrm{MgAl}$ & 42.86 & 4.212 & 16.9 & $\begin{array}{c}\mathrm{MgO} \text { or solid } \\
\text { solution }\end{array}$ & $66.2^{* * *}$ & 1.88 \\
& & & & & \\
\hline
\end{tabular}

* Crystallite size calculated using the Scherrer equation.

** Considering that the peak at $42.86^{\circ}$ correspond only to $\mathrm{MgO}$.

*** From Rietveld refinement.

Despite the economic and environmental benefits of this process, there is not yet a DRM full scale plant operation up to date [3]. The main reasons are the high energy requirements of the reaction and the fast deactivation of the catalysts due to coke deposition and sintering of both support and active phase at high reaction temperatures.

So, much effort has been done to develop thermally stable catalysts with good performance for this process. Supported noble metal $(\mathrm{Ru}, \mathrm{Pd}$, $\mathrm{Pt}$ and $\mathrm{Rh}$ ) catalysts proved to have good catalytically performance. However, their high cost and limited availability are significant drawbacks [4-6]. So, transition metals, especially $\mathrm{Ni}$, have been widely studied due to their lower cost and higher accessibility compared to noble metals and proven activity in this process [7]. Nevertheless, they were reported to be more prone to carbon deposition on the catalyst surface (Eqs. (2) and (3)) and present low resistance against the sintering of the active phase, which considerably reduce their stability [1,8-10].

Boudouard reaction:

$2 \mathrm{CO} \leftrightarrow \mathrm{C}_{(\mathrm{s})}+\mathrm{CO}_{2}$

$\Delta H^{\circ}{ }_{298}=-172 \mathrm{~kJ} / \mathrm{mol} ; \Delta G^{\circ}=-39810+40.87 \mathrm{~T}$
$\mathrm{CH}_{4} \leftrightarrow \mathrm{C}_{(\mathrm{s})}+2 \mathrm{H}_{2}$

$\Delta H^{\circ}{ }_{298}=75 \mathrm{~kJ} / \mathrm{mol} ; \Delta G^{\circ}=2190-26.75 \mathrm{~T}$

So, there has been many studies to improve the coke resistance of the Ni-based catalysts. One possible pathway is the addition of alkali promoters, which increase the basicity of the support and favors the $\mathrm{CO}_{2}$ adsorption which will further oxidize the carbon deposit [11-15]. According to Ballarini et al. [14], these promoters may act as texture, structure and activity promoters, enhancing the thermal stability of the alumina-based supports and preventing sintering of the support and of the active phase. They would also improve the metal dispersion and the ability of the catalyst to gasify the coke deposit. San Jose-Alonso et al. [16] investigated the influence of potassium (K) over the performance of the $\mathrm{Co} / \mathrm{Al}_{2} \mathrm{O}_{3}$ catalyst. Promoted catalyst showed lower coke deposition compared to unpromoted catalyst. This was explained by a partial coverage of the active sites for the methane decomposition by $\mathrm{K}$ addition and its ability to catalyze the carbon gasification reaction.

Several works have demonstrated that the formation of a NiO-MgO solid solution could also hinder the deactivation by coke deposition. Bradford and Vannice [11] showed that the formation of NiO-MgO solid solution could stabilize the Ni particles, which prevented carbon deposition over $\mathrm{Ni} / \mathrm{MgO}$ catalyst in DRM reaction. Hou et al. [17] added that the combination between $\mathrm{NiO}$ and $\mathrm{MgO}$ results in a very stable solid solution with a basic character, which is efficient in inhibiting the coke deposit.

Addition of water to the feed has also been used to inhibit carbon formation via a carbon gasification reaction (Eq. (4)) [11].

Carbon gasification:

$\mathrm{C}_{(\mathrm{s})}+\mathrm{H}_{2} \mathrm{O} \leftrightarrow \mathrm{H}_{2}+\mathrm{CO} \quad \Delta H^{\circ}{ }_{298}=131 \mathrm{~kJ} / \mathrm{mol}$

Rostrup-Nielsen [18] showed that the coke could be gasified by different gases such as hydrogen, carbon dioxide and steam. However, steam would be the most effective one. Similar conclusions were obtained by Figueiredo et al. [19]. They showed that the rate of coke gasification with hydrogen is considerably slower than with steam.

In the present work, $\mathrm{Ni}$ supported on $\mathrm{Mg}$-doped $\mathrm{Al}_{2} \mathrm{O}_{3}$ catalysts, with different amounts of MgO, were tested in the DRM reaction. The aim was to understand the influence of the catalysts basicity (linked to the amount of $\mathrm{Mg}$ ) on the catalyst activity and stability, and the role of the water formed during the reaction. The novelty of this work is the successful combination of different methods for structural characterization of catalysts before and after catalytic test to understand the deactivation mechanism and the impact on the conversion of $\mathrm{CO}_{2}$ and $\mathrm{CH}_{4}$ into syngas. The water formed during the reaction could be experimentally quantified and linked to the catalytic performance of catalysts synthesized in this work. This contributes to the basic understanding of DRM process and to the design of an efficient catalyst for DRM.

Methane cracking reaction:
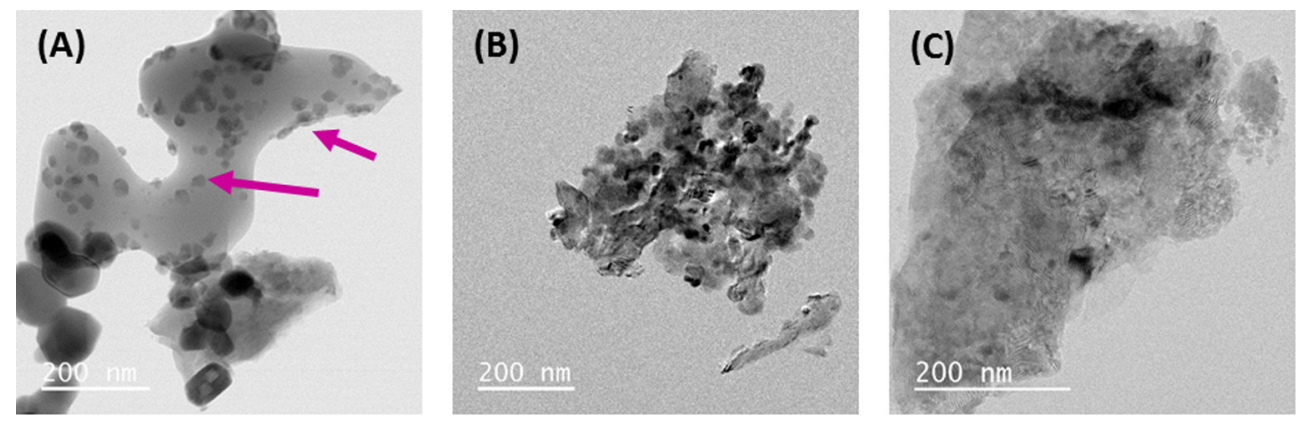

Fig. 2. TEM of fresh catalysts: (a) $\mathrm{Ni} / \mathrm{Al}$, (b) $\mathrm{Ni} / 30 \mathrm{MgAl}$ and (c) $\mathrm{Ni} / 70 \mathrm{MgAl} ; \rightarrow$ pink arrow: nickel particle. (For interpretation of the references to colour in this figure legend, the reader is referred to the web version of this article.) 

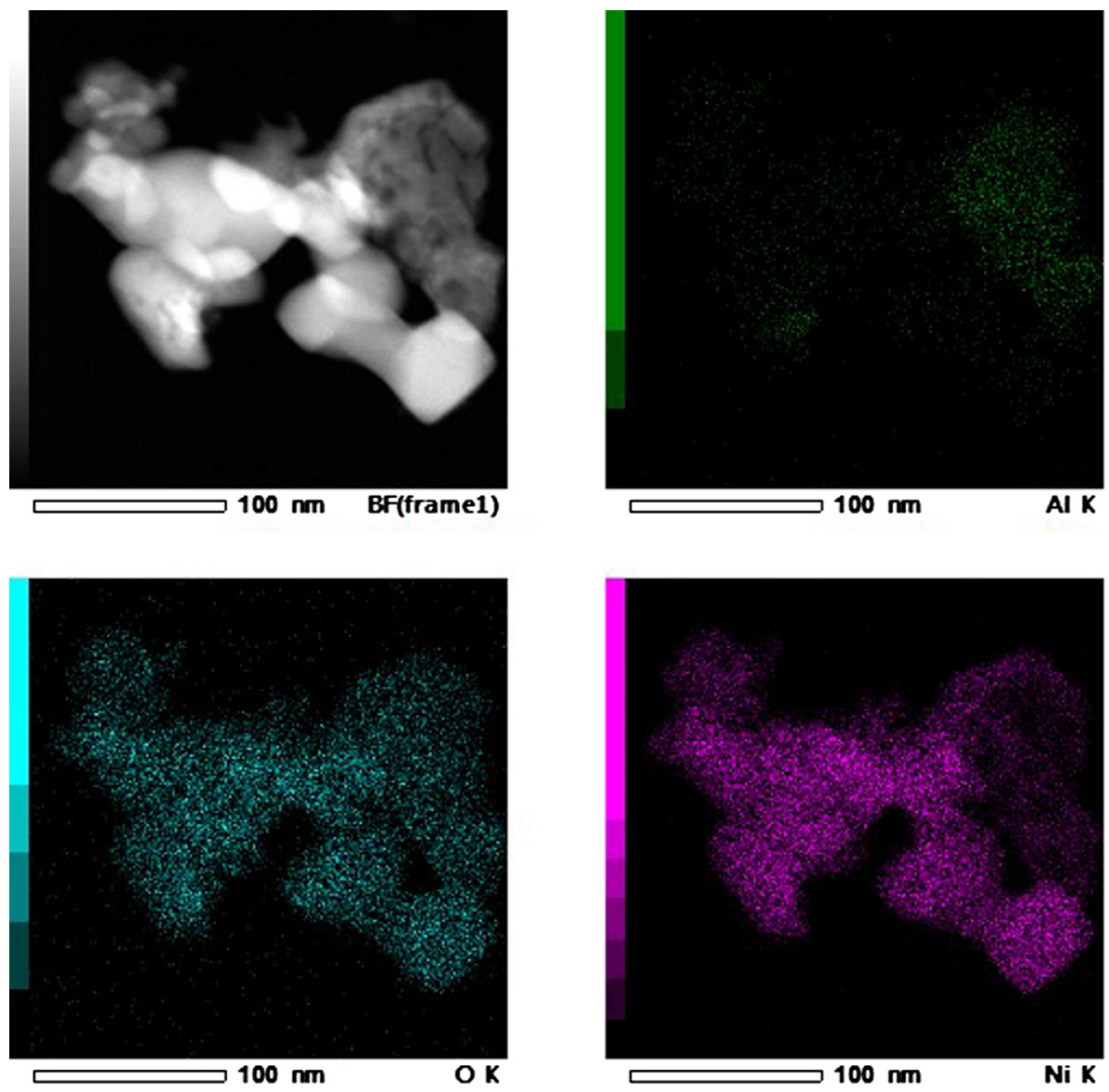

Fig. 3. EDX mapping of $\mathrm{Ni} / \mathrm{Al}$ catalyst.
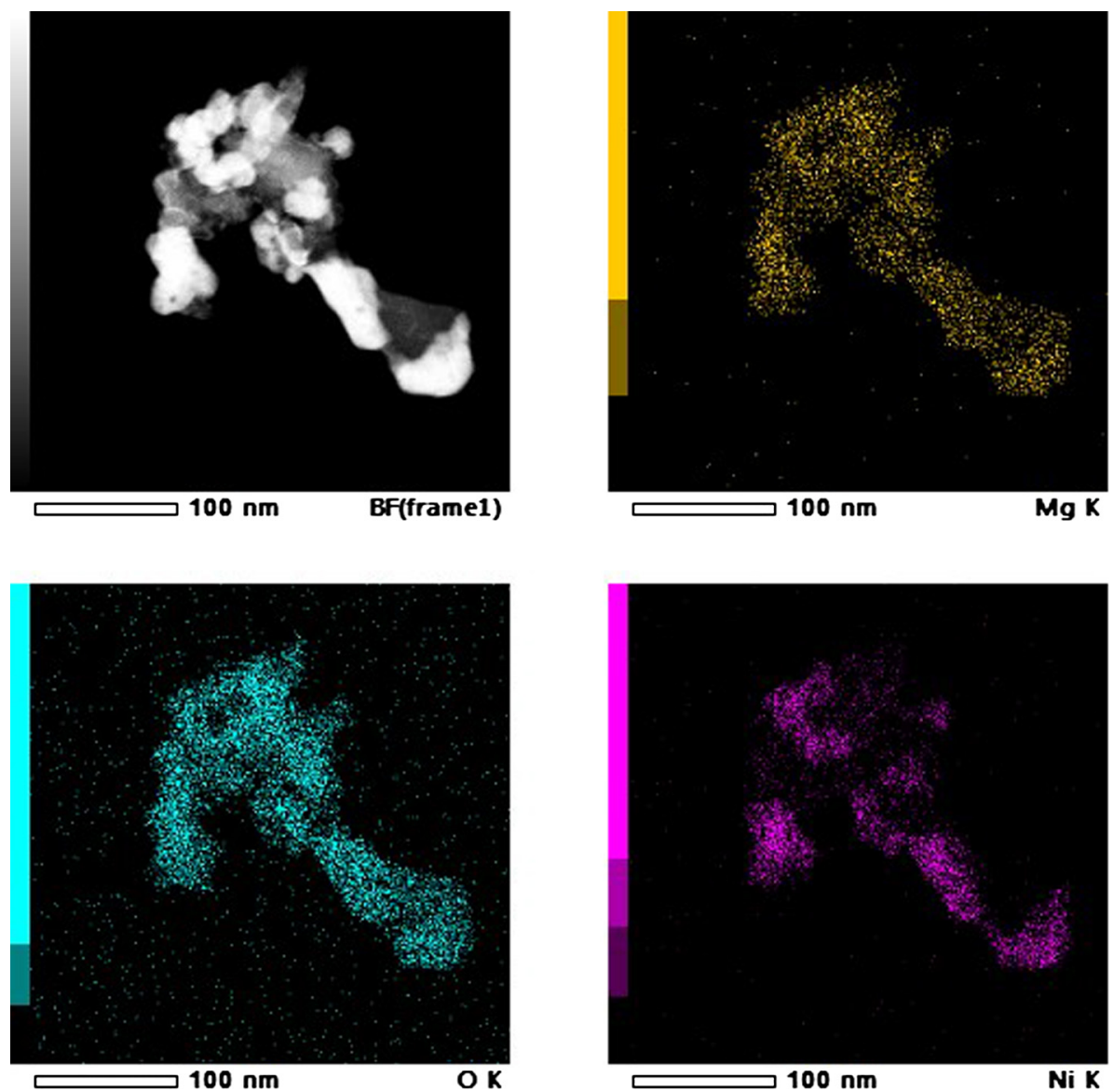

Fig. 4. EDX mapping of $\mathrm{Ni} / 30 \mathrm{MgAl}$ catalyst 

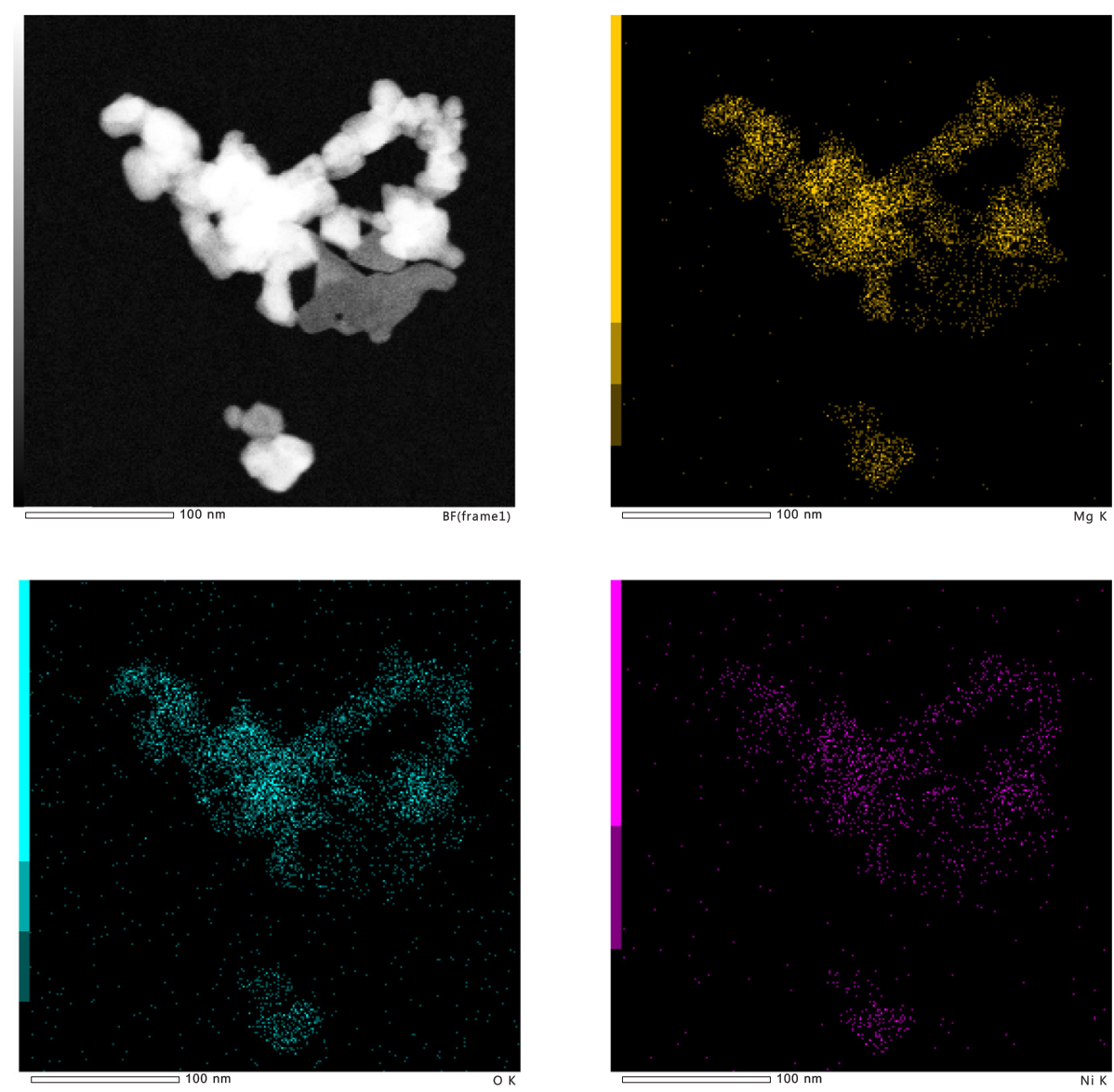

Fig. 5. EDX mapping of $\mathrm{Ni} / 70 \mathrm{MgAl}$ catalyst.

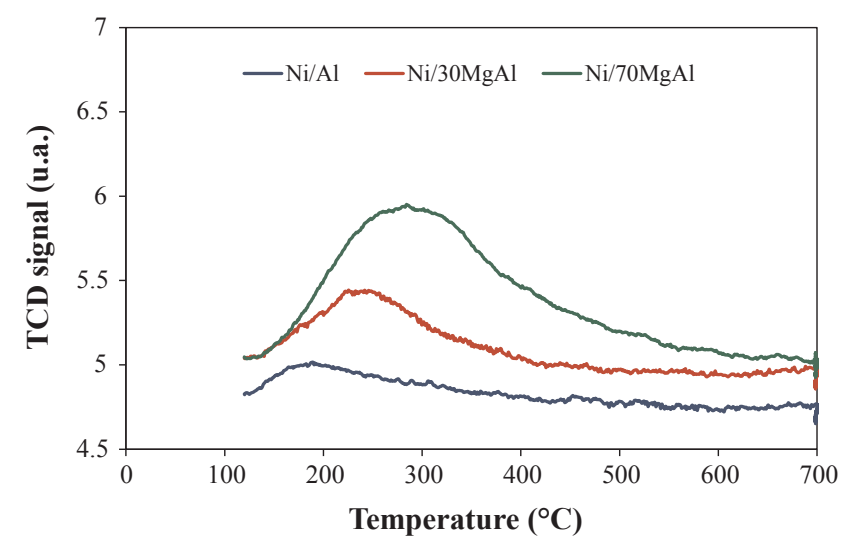

Fig. 6. $\mathrm{CO}_{2}$-TPD profiles of the alumina-based catalysts.

\section{Materials and methods}

\subsection{Catalyst preparation}

Commercial $\gamma-\mathrm{Al}_{2} \mathrm{O}_{3}$ and hydrotalcite-based supports (PURAL ${ }^{\oplus} \mathrm{MG}$ ) provided by Sasol (Germany) were employed as catalysts supports. In this work, two hydrotalcite-based supports with different $\mathrm{MgO} / \mathrm{Al}_{2} \mathrm{O}_{3}$ weight ratios were used: PURAL MG30 (30:70) and PURAL MG70 (70:30). The three supports $\left(\mathrm{Al}_{2} \mathrm{O}_{3}\right.$, PuralMG30 and PuralMG70) were first sintered at $1200^{\circ} \mathrm{C}$ for $5 \mathrm{~h}$ in order to stabilize them and avoid later catalyst deactivation by support sintering. Then, the catalysts were prepared by impregnating the sintered supports with an aqueous solution of $\mathrm{Ni}\left(\mathrm{NO}_{3}\right)_{2} \cdot 6 \mathrm{H}_{2} \mathrm{O}$ (Fisher Scientific) by incipient wetness impregnation method. The loading amount of $\mathrm{Ni}$ was $5.7 \mathrm{wt} \%$ for each sample. After the impregnation, the powder was dried at $105^{\circ} \mathrm{C}$. No further calcination was performed prior to the catalytic tests since the temperature employed during the reduction and reaction phases $\left(700{ }^{\circ} \mathrm{C}\right)$ are enough to decompose the water and nitrates from the catalyst and these are the only species decomposed during a calcination of these catalysts (Fig. S1, supplementary material). The catalysts are referred as $\mathrm{Ni} / \mathrm{Al}, \mathrm{Ni} / 30 \mathrm{MgAl}$ and $\mathrm{Ni} / 70 \mathrm{MgAl}$ for $\mathrm{Al}_{2} \mathrm{O}_{3}$, PuralMG30 and PuralMG70 supports, respectively.

\subsection{Catalytic reaction}

The dry reforming of methane was carried out in a fixed-bed tubular reactor ( $8 \mathrm{~mm}$ i.d.). $300 \mathrm{mg}$ of catalyst was diluted 2 times with nonporous alumina powder, which was then placed at the center of the reactor, between two layers of the same non-porous alumina. The pressure drop in the reactor was 1.6 bar. The reaction temperature was controlled by a thermocouple inserted into the reactor at the center of the catalytic bed. The catalyst was reduced in situ at $700{ }^{\circ} \mathrm{C}$ for $2 \mathrm{~h}$ under $4 \% \mathrm{H}_{2} / \mathrm{N}_{2}$ with a flow rate of $70 \mathrm{~mL} / \mathrm{min}$. After the reduction step, the reaction was carried out at $700{ }^{\circ} \mathrm{C}$ with a WHSV of $15,882 \mathrm{~mL} \mathrm{~h}^{-1} \mathrm{~g}_{\text {cat }}{ }^{-1}$ with a synthetic gas mixture containing $20 \%$ of $\mathrm{CH}_{4}, 20 \%$ of $\mathrm{CO}_{2}$ and $60 \%$ of $\mathrm{N}_{2}$ (volume percentage) for $50 \mathrm{~h}$ of TOS (time on stream). A silica gel tube was placed at the outlet of the reactor as water trap for the quantification of water formed during the reaction. Gas products were analyzed by a $\mu$-GC A3000 (Agilent) equipped with a thermal conductivity detector (TCD). A gas counter was also used for the measurement of the total gas flow rate at the reactor outlet. This is mandatory for correctly determining the selectivity and mass balance of the process.

The deactivation rate of the catalysts was calculated as follows: 

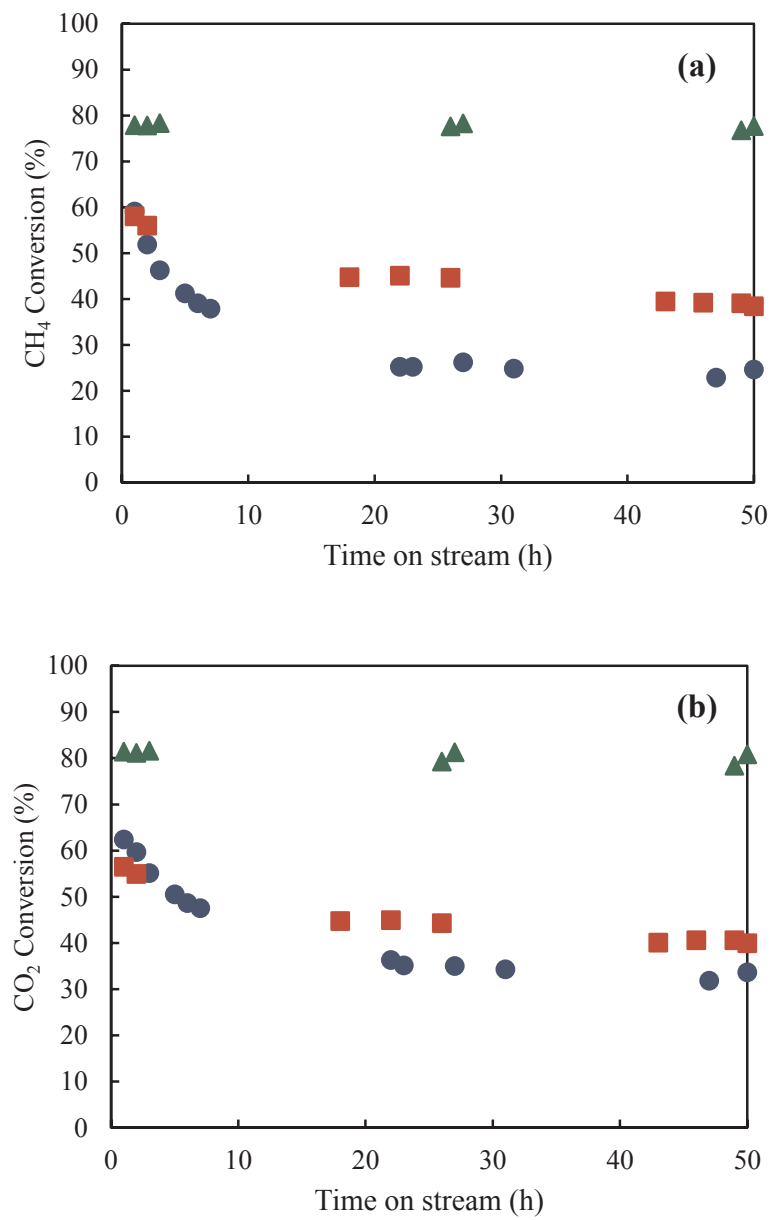

Fig. 7. $\mathrm{CH}_{4}$ (a) and $\mathrm{CO}_{2}$ (b) conversions as a function of TOS for the prepared catalysts (reaction conditions: $700^{\circ} \mathrm{C}, 1.6 \mathrm{bar}, 15,882 \mathrm{~mL} \mathrm{~h}^{-1} \mathrm{~g}_{\text {cat }}{ }^{-1}$ ): $\bullet ~ \mathrm{Ni} / \mathrm{Al}$; — Ni/30MgAl; $\triangle \mathrm{Ni} / 70 \mathrm{MgAl}$.

Deactivation rate $(\%)$ $=\frac{\mathrm{CH}_{4} \text { conversion after } 1 \mathrm{~h} \text { of TOS }-\mathrm{CH}_{4} \text { conversion after } \mathrm{X} \mathrm{h}}{X-1} \times 100$

where: $X$ being equal to 26 or $50 \mathrm{~h}$.

\subsection{Catalyst characterization}

X-ray diffraction (XRD) patterns of the powdered samples previously calcined at $700{ }^{\circ} \mathrm{C}$ under air for $3 \mathrm{~h}$ were obtained using a Phillips Panalytical X'Pert MPD diffractometer operating with $\mathrm{Cu} \mathrm{Ka}$ radiation $\left(\lambda=1.543 \AA\right.$ ) over a $2 \theta$ range of $10-150^{\circ}$ and scan step size of $0.042^{\circ} \mathrm{s}^{-1}$. Crystallite size was obtained using the Scherrer equation.

$\mathrm{N}_{2}$ adsorption isotherms were recorded with a Micromeritics Tristar II 3020 in order to analyze the specific surface area and the porosity of the fresh catalysts. BET surface area was calculated from the nitrogen adsorption isotherms. Prior to the analyses, the catalysts samples were outgassed at $105^{\circ} \mathrm{C}$ for $24 \mathrm{~h}$ at low pressure ( $<100 \mathrm{mbar}$ ).

Basicity of the catalysts previously calcined at $700{ }^{\circ} \mathrm{C}$ under air for $3 \mathrm{~h}$ was investigated by carbon dioxide temperature-programmed desorption $\left(\mathrm{CO}_{2}\right.$-TPD) using a Micromeritics AutoChem 2920 Analyzer equipped with a thermal conductivity detector (TCD). For each measurement, $100 \mathrm{mg}$ of the sample was pretreated at $700^{\circ} \mathrm{C}\left(10^{\circ} \mathrm{C} / \mathrm{min}\right)$ under helium flow for $1 \mathrm{~h}$. The sample was then reduced under a flow of $25 \mathrm{~mL} / \mathrm{min}$ of $5 \% \mathrm{H}_{2} / \mathrm{N}_{2}$ for $1 \mathrm{~h}$ and then it was cooled to $50{ }^{\circ} \mathrm{C}$ at $10{ }^{\circ} \mathrm{C} /$ min under helium flow. The samples were then saturated with $5 \% \mathrm{CO}_{2} /$ $\mathrm{N}_{2}(15 \mathrm{~mL} / \mathrm{min})$ for $30 \mathrm{~min}$, before being flushed with helium $(25 \mathrm{~mL} /$ min) for $1 \mathrm{~h}$ in order to eliminate physisorbed $\mathrm{CO}_{2}$ molecules. TPD was finally performed from 50 to $700^{\circ} \mathrm{C}$ at a heating rate of $10^{\circ} \mathrm{C} / \mathrm{min}$.

Transmission electron microscopy (TEM) images of the fresh catalysts calcined at $700{ }^{\circ} \mathrm{C}$ under air for $3 \mathrm{~h}$ and of the spent catalysts were recorded on a MET JEOL JEM-ARM200F-EDX/EELS. EDX mapping was also performed on the fresh calcined catalysts.

Thermogravimetric analyses (TGA) of spent catalysts were realized in order to qualitatively determine the different types of carbon deposit over the catalysts after the reaction. The analyses were carried out on a SDT Q600 apparatus from TA instruments. $30 \mathrm{mg}$ of the spent catalyst was introduced into an alumina crucible. The sample was then heated under air flow $(100 \mathrm{~mL} / \mathrm{min})$ up to $1000^{\circ} \mathrm{C}$ at a heating rate of $1{ }^{\circ} \mathrm{C}$ / min.

\section{Results and discussion}

\subsection{Textural, structural and chemical features of the fresh catalysts}

XRD patterns of fresh catalysts calcined at $700{ }^{\circ} \mathrm{C}$ under air for $3 \mathrm{~h}$ are presented in Fig. 1. For the $\mathrm{Al}$ support, a phase transition of $\gamma-\mathrm{Al}_{2} \mathrm{O}_{3}$ to $\alpha-\mathrm{Al}_{2} \mathrm{O}_{3}$ was observed as expected. In fact, the $\alpha-\mathrm{Al}_{2} \mathrm{O}_{3}$ phase is usually formed during a high temperature calcination process [14]. The nickel crystallite size on the catalyst $\mathrm{Ni} / \mathrm{Al}$ was estimated around at $19 \mathrm{~nm}$.

XRD patterns of the $30 \mathrm{MgAl}$ support showed the only the presence of the $\mathrm{MgAl}_{2} \mathrm{O}_{4}$ phase. The $\mathrm{Ni} / 30 \mathrm{MgAl}$ catalyst showed the presence of the $\mathrm{MgAl}_{2} \mathrm{O}_{4}$ phase and also another phase that could be either $\mathrm{NiO}$ or $\mathrm{MgO}$ or, most likely, a NiO-MgO solid solution due to the thermal treatment applied to the catalyst. In fact, it has been extensively reported in the literature that $\mathrm{NiO}$ and $\mathrm{MgO}$ oxides have a NaCl-like lattice structure with very similar lattice parameters. Feng et al. [20] reported that for $\mathrm{MgO}$, the $2 \theta$ values match at $62.6^{\circ}$ (2 20$), 75^{\circ}$ (3 11 ) and $79^{\circ}(222)$, while for $\mathrm{NiO}$ these values match at $63.2^{\circ}, 75.8^{\circ}$ and $79.81^{\circ}$. Moreover, $\mathrm{Ni}^{2+}$ ionic radius is $0.070 \mathrm{~nm}$ while the $\mathrm{Mg}^{2+}$ radius is $0.065 \mathrm{~nm}$. These structural similarities explain why $\mathrm{NiO}$ and $\mathrm{MgO}$ can easily form a solid solution [20-23].

The $70 \mathrm{MgAl}$ support presented the $\mathrm{MgAl}_{2} \mathrm{O}_{4}$ phase, along with $\mathrm{MgO}$ phase, with particle size of $12.8 \mathrm{~nm}$ (Table 1 ). The $\mathrm{Ni} / 70 \mathrm{MgAl}$ catalyst still presented $\mathrm{MgAl}_{2} \mathrm{O}_{4}$ and it also presented another phase that could be related to $\mathrm{MgO}$ or to a NiO-MgO solid solution. To confirm the presence of a NiO-MgO solid solution, the crystallite size and quantitative analysis were performed using Rietveld refinement. It is worth noting that $\mathrm{MgO}$ crystallite size in the initial $70 \mathrm{MgAl}$ support was of $12.8 \mathrm{~nm}$ (Table 1). On the other hand, the crystallite size of the possible $\mathrm{MgO}$ phase in $\mathrm{Ni} / 70 \mathrm{MgAl}$ catalyst was of $16.9 \mathrm{~nm}$. This result suggests the insertion of $\mathrm{Ni}^{2+}$ ions into the initial $\mathrm{MgO}$ lattice leading to the formation of a NiO-MgO solid solution. Moreover, the $70 \mathrm{MgAl}$ support contained only $59.7 \mathrm{wt} \%$ of $\mathrm{MgO}$. It was $66.2 \mathrm{wt} \%$ in the $\mathrm{Ni} / 70 \mathrm{MgAl}$ catalyst considering that the major peak at $42.86^{\circ}$ corresponded only to $\mathrm{MgO}$ (Table 1). In addition, no other crystalline phase of nickel oxide was detected in this catalyst. This confirms the formation of the NiO$\mathrm{MgO}$ solid solution. Similar results were obtained by Feng et al. [20]. Rietveld refinement fitted the measured XRD patterns satisfactorily as indicated by the low values of $\mathrm{R}_{\mathrm{Bragg}}$ parameter.

BET surface areas $\left(\mathrm{S}_{\mathrm{BET}}\right)$ and pore volumes $\left(\mathrm{V}_{\mathrm{p}}\right)$ measurements of the supports and catalysts revealed negligible $S_{\mathrm{BET}}$ and $\mathrm{V}_{\mathrm{p}}$, as expected since the supports were previously sintered for stabilization.

TEM images of the fresh catalysts are illustrated in Fig. 2. Ni/Al catalyst (Fig. 2a) presented well distinguished Ni-based particles of size around $10-50 \mathrm{~nm}$. The formation of distinguished Ni-based particles (nickel oxide particles, as previously identified by XRD analysis) are confirmed by the EDX mapping presented in Fig. 3. Indeed, this figure highlighted the association between $\mathrm{Ni}$ and $\mathrm{O}$. However, the $\mathrm{Ni}$ is not associated with the $\mathrm{Al}$, highlighting the formation of well-defined nickel oxide particles. Ni-based particles on both $\mathrm{Ni} / 30 \mathrm{MgAl}$ (Fig. $2 \mathrm{~b}$ ) and $\mathrm{Ni}$ / $70 \mathrm{MgAl}$ catalysts (Fig. 2c) were not well-defined so their size could not 

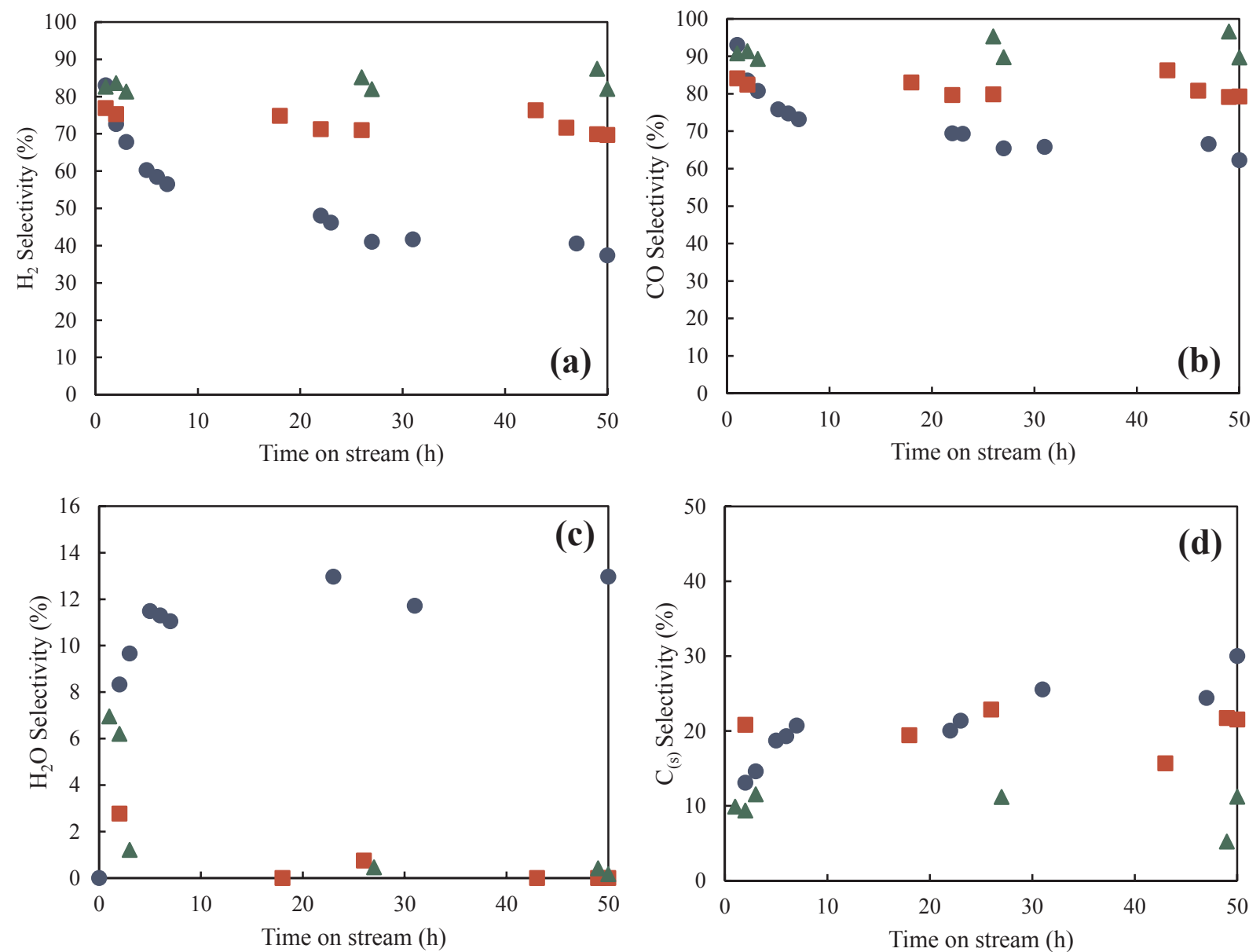

Fig. 8. Selectivity in (a-b) desired $\left(\mathrm{H}_{2}\right.$ and $\left.\mathrm{CO}\right)$ and (c-d) undesired $\left(\mathrm{H}_{2} \mathrm{O}\right.$ and $\left.\mathrm{C}_{\mathrm{s}}\right)$ products: $\bullet \mathrm{Ni} / \mathrm{Al} ; \mathbf{\mathrm { Ni }} / 30 \mathrm{MgAl} ; \mathbf{\Delta} \mathrm{Ni} / 70 \mathrm{MgAl}$.

Table 2

Deactivation rates of the alumina-based catalysts.

\begin{tabular}{lcc}
\hline Catalysts & $\begin{array}{c}\text { Deactivation rate }\left(\% \mathrm{~h}^{-1}\right) \\
\text { at TOS }=26 \mathrm{~h}\end{array}$ & $\begin{array}{c}\text { Deactivation rate }\left(\% \mathrm{~h}^{-1}\right) \\
\text { at TOS }=50 \mathrm{~h}\end{array}$ \\
\hline $\mathrm{Ni} / \mathrm{Al}$ & 1.09 & 0.70 \\
$\mathrm{Ni} / 30 \mathrm{MgAl}$ & 0.54 & 0.40 \\
$\mathrm{Ni} / 70 \mathrm{MgAl}$ & 0.01 & 0.004 \\
\hline
\end{tabular}

be estimated. Moreover, the EDX mapping results of these catalysts (Fig. 4 and Fig. 5, respectively) showed that $\mathrm{Ni}$ is always associated to all the other species, highlighting the formation of NiO-MgO solid solution as previously identified by the XRD results.

$\mathrm{CO}_{2}$-TPD experiments were conducted in order to evaluate the amount and the strength of basic sites presented in each catalyst. The objective was to show how the amount of $\mathrm{MgO}$ would influence the basicity of the supports and possibly help the coke removal. The amount of the basic sites is represented by the area under the $\mathrm{CO}_{2}$-TPD curves and the strength of the sites is related to the temperature of $\mathrm{CO}_{2}$ desorption. It has been reported that high desorption temperatures ( $\mathrm{T}>300^{\circ} \mathrm{C}$ ) indicate the presence of strong basic sites, while temperatures between 200 and $300{ }^{\circ} \mathrm{C}$ and lower than $200{ }^{\circ} \mathrm{C}$ represent medium and weak basic sites, respectively [24-27]. Fig. 6 shows the $\mathrm{CO}_{2}$-TPD profiles of the catalysts samples after impregnation and calcination at $700^{\circ} \mathrm{C}$ under air. The $\mathrm{Ni} / \mathrm{Al}$ catalyst showed a small desorption peak at around $185^{\circ} \mathrm{C}$, indicating the presence of only small amounts of medium basic sites. This result was not surprising since alumina is known to be an acidic material [24]. The $\mathrm{Ni} / 30 \mathrm{MgAl}$ catalyst presented a desorption peak with the maximum at about $250{ }^{\circ} \mathrm{C}$, also implying the presence of medium basic sites. However, the area under the $\mathrm{CO}_{2}$-TPD curve of this catalyst was larger than the one obtained with the $\mathrm{Ni} / \mathrm{Al}$ catalyst, indicating that the total amount of basic sites was larger for the $\mathrm{Ni} / 30 \mathrm{MgAl}$ catalyst, as expected due to the presence of Mg. This result is rather interesting confirming that the formation of a NiO-MgO solid solution did not eliminate the basic sites present initially on the $30 \mathrm{MgAl}$ support due to the presence of $\mathrm{MgO}$. The $\mathrm{Ni} /$ $70 \mathrm{MgAl}$ catalyst showed a very broad desorption peak ranging from 100 to almost $500{ }^{\circ} \mathrm{C}$, indicating the presence of weak, medium and strong basic sites. Moreover, this catalyst presented the largest area under the curve, indicating a larger amount of basic sites. The difference between the two Mg-containing catalysts could be related to the initial MgO contents on the supports. Ballarini et al. [14] and Montanari et al. [28] reported that only high amounts of alkali and alkaline earth metals could produce significant amount of different basic sites for alumina-based support, which is the case of the $70 \mathrm{MgAl}$ support. Once again, the formation of a NiO-MgO solid solution did not eliminate the basic sites related to the presence of $\mathrm{Mg}$. This is an important parameter since catalysts which are able to strongly adsorb $\mathrm{CO}_{2}$ tend to present high catalytic stability in processes such as DRM. In fact, $\mathrm{CO}_{2}$ can gasify coke deposit preventing the catalyst deactivation [11].

\subsection{DRM test}

The catalytic performance of the prepared catalysts during DRM reaction at $700{ }^{\circ} \mathrm{C}$ is shown in Fig. 7 . Also, the selectivity to syngas (desired product) and in water and solid carbon (undesired products) are shown in Fig. 8. The real amount of carbon deposited over the catalyst sample could not be measured due to the dilution applied to the 

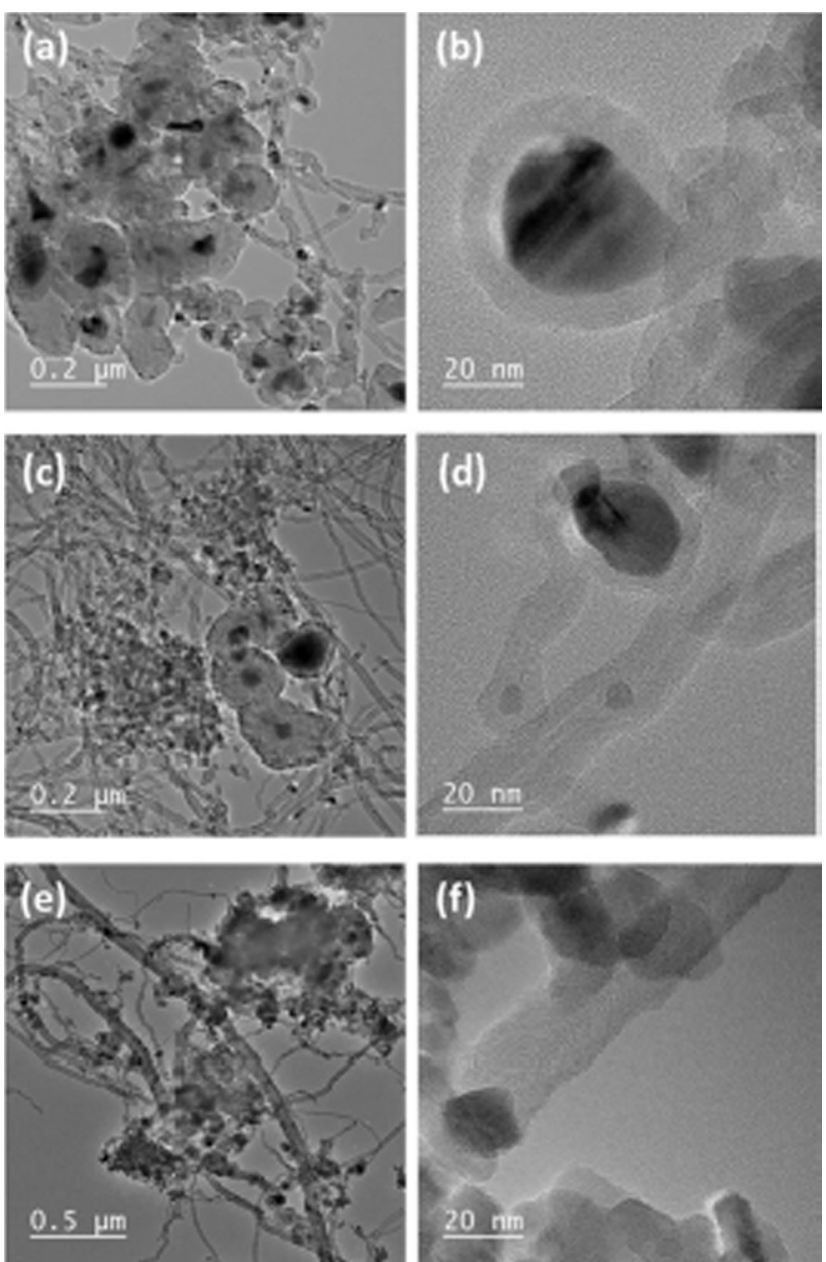

Fig. 9. TEM images of spent catalysts after $50 \mathrm{~h}$ of TOS: (a) and (b) Ni/Al; (c) and (d) Ni/30MgAl; (e) and (f) Ni/70MgAl.

catalyst that rendered the sample very heterogeneous. So, the solid carbon selectivity was calculated based on the carbon mass balance.

$\mathrm{Ni} / 70 \mathrm{MgAl}$ catalyst showed the best performance under the experimental conditions used. The conversion of methane and carbon dioxide was stable and kept around $80 \%$ over $50 \mathrm{~h}$ of time on stream (TOS). The selectivity to syngas was also very high $(\approx 80-90 \%)$ and was kept constant during the test. In consequence, very low $\mathrm{H}_{2} \mathrm{O}$ and $\mathrm{C}_{(\mathrm{s})}$ selectivity were observed. The low amounts of water and solid carbon indicate the occurrence of the carbon gasification reaction (Eq. (4)), where the carbon deposit reacts with the water formed to increase the syngas production. Moreover, the presence of strong basic sites in this catalyst favored $\mathrm{CO}_{2}$ adsorption and consequently the solid carbon gasification (by adsorbed $\mathrm{CO}_{2}$ ) through Boudouard reaction (Eq. (2)). This explains the low deactivation rate (only $0.004 \% / \mathrm{h}$ at $50 \mathrm{~h}$ of TOS) of this catalyst (Table 2).

Finally, Ni/Al catalyst, which had negligible support basicity, showed high initial methane and carbon dioxide conversions $(\approx 60 \%)$. However, they drastically decreased to $\approx 20-30 \%$ during the first $26 \mathrm{~h}$ of TOS before becoming relatively stable. Similarly, the initial syngas selectivity was very high $(\approx 80 \%)$ and then it drastically decreased during the first $26 \mathrm{~h}$ of TOS. Consequently, high $\mathrm{H}_{2} \mathrm{O}(\approx 12 \%)$ and $\mathrm{C}_{(\mathrm{s})}$ $(\approx 30 \%)$ selectivity were observed after $26 \mathrm{~h}$ of TOS. This could be explained by the occurrence of side reactions such as reverse water-gas shift $\left(\mathrm{CO}_{2}+\mathrm{H}_{2} \mathrm{CO}+\mathrm{H}_{2} \mathrm{O} \quad \Delta \mathrm{H}^{\circ}{ }_{298} \rightleftharpoons=41.2 \mathrm{~kJ} / \mathrm{mol}\right)$, that consumes $\mathrm{H}_{2}$ and $\mathrm{CO}_{2}$ to produce $\mathrm{H}_{2} \mathrm{O}$ and $\mathrm{CO}$ and also Boudouard (Eq. (2)) and methane cracking reactions (Eq. (3)), which are responsible for coke deposition on catalyst surface. This could explain the high deactivation rate $(0.70 \% / \mathrm{h}$ at $50 \mathrm{~h}$ of TOS) of this catalyst (Table 2 ).

Methane and carbon dioxide conversions were slightly higher with $\mathrm{Ni} / 30 \mathrm{MgAl}$ than with $\mathrm{Ni} / \mathrm{Al}$ catalyst. $\mathrm{Ni} / 30 \mathrm{MgAl}$ catalyst still presented considerably high methane and carbon dioxide conversions $(\approx 40-50 \%)$ after $50 \mathrm{~h}$ of TOS. Syngas selectivity obtained with this catalyst slightly decreased from 78 to $72 \%$ for $\mathrm{H}_{2}$, and 84 to $79 \%$ for $\mathrm{CO}$ during $50 \mathrm{~h}$ of TOS. However, its deactivation rate $(0.40 \% / \mathrm{h}$ at $50 \mathrm{~h}$ of TOS) was much smaller (Table 2) compared to pure alumina-based catalyst $(0.7 \% / \mathrm{h}$ at $50 \mathrm{~h}$ of TOS). Only trace amount of water was observed which suggests that $\mathrm{MgO}$ could promote the carbon gasification (Eq. (4)). However, high carbon deposition still took place with the selectivity in solid carbon around $20 \%$ after $50 \mathrm{~h}$ of TOS.

It is worth noticing that all three catalysts presented high deactivation rate during the first $26 \mathrm{~h}$ of TOS (Table 2), which indicates that the carbon deposition reactions occurred mainly during this time. Then, the process tended to equilibrium between the carbon deposition and the carbon gasification reactions.

\section{Deactivation analysis}

The main reasons for the catalyst deactivation are generally coke deposition, which covers the active sites, and the sintering of active phase. In order to better understand the deactivation of the prepared catalysts, TEM and TGA analyses of the spent catalysts were realized.

The morphology of the spent catalysts was observed by TEM with the emphasis on the size of the metal-based particles and on the coke deposit. The TEM images of the three spent catalysts are shown in Fig. 9.

The screening of different regions of $\mathrm{Ni} / \mathrm{Al}$ spent catalyst (Fig. 9a and $b$ ) revealed the presence of significant amount of carbon deposit under core-shell structure, which covered the nickel-based particles. This type of carbon deposit leads to a complete coverage of the active sites, and consequently to the catalyst deactivation. Wang et al. [29] reported that the formation of the core-shell/graphite layers structures occurs when the carbon diffusion rate is low, leading to the retention of carbon on the surface of the Ni-based particles. The diffusion of the carbon species through the Ni-based particles also resulted in the formation of carbon nanotubes (CNTs) and carbon nanofibers (CNFs). Moreover, the size of Ni-based particles on the spent catalyst was around $50-60 \mathrm{~nm}$ while it was around $10-40 \mathrm{~nm}$ on the fresh catalyst (Fig. 2a). So the sintering of the active phase occurred during the reaction, which is also known to be responsible for the catalyst deactivation.

Spent $\mathrm{Ni} / 30 \mathrm{MgAl}$ catalyst (Fig. 9c and d) also showed the presence of core-shell carbon. However, the carbon deposit occurred mostly under CNTs/CNFs form. Sintering of the nickel-based particles was also observed for this sample since the spent catalyst clearly showed nickelbased particles around $10-60 \mathrm{~nm}$ while they were not detectable on the fresh sample.

$\mathrm{Ni} / 70 \mathrm{MgAl}$ catalyst (Fig. 9e and f) showed rarely core-shell carbon and CNTs/CNFs. Sintering of the nickel-based particles also occurred with the observation of small nickel-based particles (around 10-20 nm) which was not the case for the fresh sample.

The three samples showed the formation of whisker carbon (CNTs and CNFs). In some cases, the CNTs/CNFs embedded the active phase and thus contributed to the deactivation of the catalysts. However, it has been proved in the literature that this type of carbon has little influence on the catalysts deactivation. In fact, they mostly grow away from the catalyst surface and do not cover the active sites. Furthermore, in some cases, the active phase is located at the tip of the carbon structure and thus still accessible to the reactants [29-32].

The comparison between TEM results and the deactivation rate (Table 2) of the catalysts revealed that besides the amount of carbon, the type of carbon deposited on the catalyst and the sintering of the active phase are crucial for the catalyst stability. $\mathrm{Ni} / \mathrm{Al}$ catalyst, which showed the highest deactivation rate at $50 \mathrm{~h}$ of TOS $(0.70 \% / \mathrm{h})$, strongly 

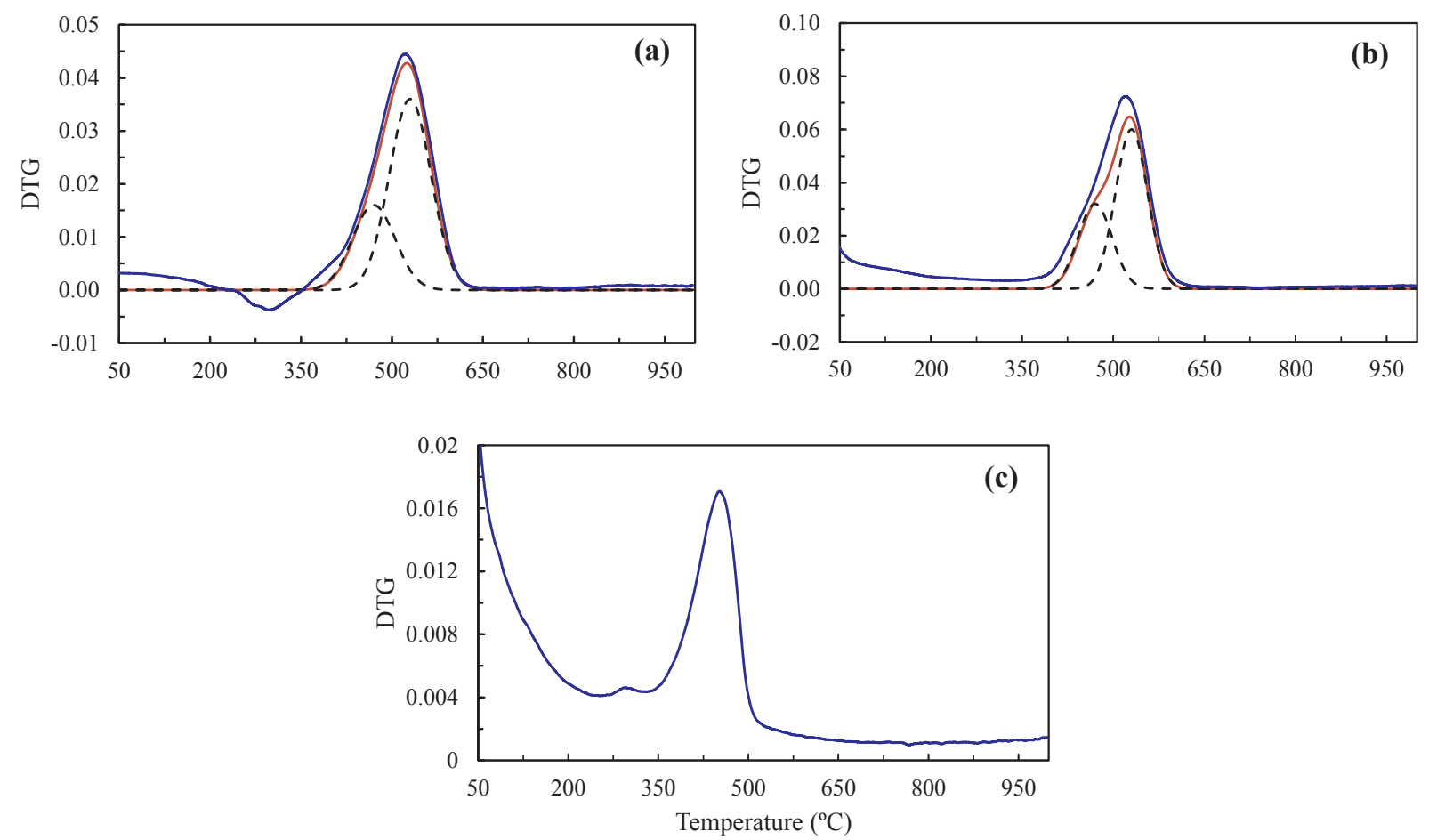

Fig. 10. TGA/DTG curves of the spent catalysts: (a) Ni/Al, (b) Ni/30MgAl, (c) Ni/70MgAl. — Blue line: original DTG curves; — red line: simulated DTG curves; — dashed line: deconvoluted peaks. (For interpretation of the references to colour in this figure legend, the reader is referred to the web version of this article.)

favored the formation of core-shell carbon and the sintering of the nickel-based particles. Conversely, the $\mathrm{Ni} / 70 \mathrm{MgAl}$ catalyst, which presented the lowest deactivation rate at $50 \mathrm{~h}$ of TOS $(0.004 \% / \mathrm{h})$, showed the lowest amount of core-shell carbon and the lowest degree of sintering of the active phase.

Thermogravimetric analysis (TGA) of the spent catalysts was performed in order to determinate the type of carbon deposited over the catalysts. As different types of carbon decomposes at different temperatures, the temperature of the DTG peaks (derivation of TGA curves) were used for the identification of the nature of carbon deposition. For each sample, the analysis was repeated three times and the deviation related to DTG peak position was less than $2 \%$. In some cases, the deconvolution of DTG peaks was necessary in order to properly identify the type of carbon deposit. The deviation of deconvolution was less than $1.5 \%$. The DTG curves of the samples are presented in Fig. 10.

Three main DTG peaks could be observed at 280,450 and $550{ }^{\circ} \mathrm{C}$. Based on TEM results presented above and literature data, these peaks could be assigned to the oxidation of amorphous carbon $\left(\mathrm{C}_{\alpha}\right)$, CNTs/ $\mathrm{CNFs}\left(\mathrm{C}_{\beta}\right)$ and core-shell/graphite carbon $\left(\mathrm{C}_{\gamma}\right)$, respectively [32]. These results slightly differ from results reported in the literature. Wang et al. $[29,33]$ showed that carbon whiskers (CNTs and CNFs) would be oxidized around $500{ }^{\circ} \mathrm{C}$ and the core-shell/graphite carbon would be oxidized only at temperatures above $600{ }^{\circ} \mathrm{C}$. Zhang et al. [34] concluded that the amorphous carbon $\left(\mathrm{C}_{\alpha}\right)$, CNTs/CNFs $\left(\mathrm{C}_{\beta}\right)$ and graphite carbon $\left(\mathrm{C}_{\gamma}\right)$ would be oxidized in the temperature range of $150-220^{\circ} \mathrm{C}$, $530-600{ }^{\circ} \mathrm{C}$ and above $650^{\circ} \mathrm{C}$, respectively. However, these studies applied heating rates of $10-30^{\circ} \mathrm{C} / \mathrm{min}$, while in this work the heating rate was $1{ }^{\circ} \mathrm{C} / \mathrm{min}$, which explains the low temperatures of DTG peaks.

Both DTG and TEM results are in agreement with the catalytic results (Table 2). Both $\mathrm{Ni} / \mathrm{Al}$ and $\mathrm{Ni} / 30 \mathrm{MgAl}$ catalysts, which had high deactivation rates, led to the formation of $\mathrm{C}_{\beta}$ and $\mathrm{C}_{\gamma}$ types of carbon, which are harder to remove causing the catalyst deactivation. On the other hand, $\mathrm{Ni} / 70 \mathrm{MgAl}$ catalyst, which showed a very low deactivation rate, presented mostly $C_{\alpha}$ and $C_{\beta}$ after DRM test. As stated previously, the $\mathrm{C}_{\beta}$ carbon has little influence on the catalytic deactivation and $\mathrm{C}_{\alpha}$ is known as the active species for the syngas formation and do not contribute to the catalytic deactivation [35]. $\mathrm{C}_{\gamma}$ was rarely observed in the spent $\mathrm{Ni} / 70 \mathrm{MgAl}$ catalyst, explaining the lower deactivation rate presented by this catalyst.

\section{Conclusions}

Alumina-based supports containing various $\mathrm{MgO}$ amounts (0-70 wt $\%)$ were used for the preparation of supported nickel catalysts. The catalytic performance of these catalysts was investigated in dry reforming of methane reaction (DRM) for syngas production at $700{ }^{\circ} \mathrm{C}$ and 1.6 bar.

The basic sites on the catalysts related to the presence of $\mathrm{Mg}$ and the formation of NiO-MgO solid solutions revealed to be crucial to the performance of the catalysts. The $\mathrm{Ni} / \mathrm{Al}$ catalyst with very low amount of basic sites quickly deactivated during the first $26 \mathrm{~h}$ of TOS due to the formation of $\mathrm{C}_{\beta}$ (CNTs and CNFs) and $\mathrm{C}_{\gamma}$ (core-shell carbon), and to the sintering of the nickel-based particles.

The $\mathrm{Ni} / 30 \mathrm{MgAl}$ catalyst with medium basicity showed better catalytically performance than the $\mathrm{Ni} / \mathrm{Al}$ catalyst with a higher selectivity to syngas. The difference between their performances were mainly related to the formation of a NiO-MgO solid solution, which might have prevented the sintering of the Ni-based particles in a large extent as well as to the capacity of the catalyst to remove the coke deposit in a certain extent due to the presence of medium basic sites.

The $\mathrm{Ni} / 70 \mathrm{MgAl}$ catalyst presented better catalytically performance than two other catalysts showing a very low deactivation rate, mainly due to the presence of strong basic sites and to its ability to remove the $\mathrm{C}_{\alpha}$ and $\mathrm{C}_{\beta}$ carbon deposits. The formation of the solid solution might also have helped preventing the sintering of the active phase in a large extent and the formation of core-shell carbon that completely deactivates the active phase.

\section{Acknowledgment}

The authors gratefully acknowledge Severine Patry for her technical help on the characterization of the catalysts. 


\section{References}

[1] Newnham J, Mantri K, Amin MH, Tardio J, Bhargava SK. Highly stable and active Ni-mesoporous alumina catalysts for dry reforming of methane. Int J Hydrogen Energy 2012;37:1454-64. http://dx.doi.org/10.1016/j.ijhydene.2011.10.036.

[2] Hua B, Yan N, Li M, Zhang Y, Sun Y, Li J, et al. Novel layered solid oxide fuel cells with multiple-twinned $\mathrm{Ni} 0.8$ Co 0.2 nanoparticles: the key to thermally independent $\mathrm{CO} 2$ utilization and power-chemical cogeneration. Energy Environ Sci 2016;9:207-15. http://dx.doi.org/10.1039/C5EE03017J.

[3] Liu H, Wierzbicki D, Debek R, Motak M, Grzybek T, Da Costa P, et al. La-promoted Ni-hydrotalcite-derived catalysts for dry reforming of methane at low temperatures. Fuel 2016;182:8-16. http://dx.doi.org/10.1016/j.fuel.2016.05.073.

[4] García-Diéguez M, Finocchio E, Larrubia MÁ, Alemany LJ, Busca G. Characterization of alumina-supported $\mathrm{Pt}, \mathrm{Ni}$ and PtNi alloy catalysts for the dry reforming of methane. J Catal 2010;274:11-20. http://dx.doi.org/10.1016/j.jcat 2010.05.020.

[5] Pakhare D, Spivey J. A review of dry (CO2) reforming of methane over noble metal catalysts. Chem Soc Rev 2014;43:7813-37. http://dx.doi.org/10.1039/c3cs60395d.

[6] Shang R, Guo X, Mu S, Wang Y, Jin G, Kosslick H, et al. Carbon dioxide reforming of methane to synthesis gas over Ni/Si3N4 catalysts. Int J Hydrogen Energy 2011;36:4900-7. http://dx.doi.org/10.1016/j.ijhydene.2011.01.034.

[7] Jafarbegloo M, Tarlani A, Mesbah AW, Sahebdelfar S. Thermodynamic analysis of carbon dioxide reforming of methane and its practical relevance. Int $\mathrm{J}$ Hydrogen Energy 2015;40:2445-51. http://dx.doi.org/10.1016/j.ijhydene.2014.12.103.

[8] Gangadharan P, Kanchi KC, Lou HH. Evaluation of the economic and environmental impact of combining dry reforming with steam reforming of methane. Chem Eng Res Des 2012;90:1956-68. http://dx.doi.org/10.1016/j.cherd.2012.04.008.

[9] Boukha Z, Kacimi M, Pereira MFR, Faria JL, Figueiredo JL, Ziyad M. Methane dry reforming on Ni loaded hydroxyapatite and fluoroapatite. Appl Catal A 2007;317:299-309. http://dx.doi.org/10.1016/j.apcata.2006.10.029.

[10] Guo F, Xu J-Q, Chu W. CO2 reforming of methane over Mn promoted Ni/Al2O3 catalyst treated by N2 glow discharge plasma. Catal Today 2015;256:124-9. http:// dx.doi.org/10.1016/j.cattod.2015.02.036.

[11] Bradford MCJ, Vannice MA. CO2 reforming of CH4. Catal Rev Sci Eng 1999;41:1-42.

[12] Gao J, Zhaoyin H, Hui L, Zheng X. Dry (CO2) reforming. In: Shekhawat D, Spivey JJ, Berry DA, editors. Fuel cells technol. fuel process. 1st ed.Amsterdam: Elsevier; 2011. p. 191-221. http://dx.doi.org/10.1016/B978-0-444-53563-4.10007-0.

[13] Wang S, Lu GQ, Millar GJM. Carbon dioxide reforming of methane to produce synthesis gas over metal-supported catalysts: state of the art. Energy Fuels 1996;10:896-904.

[14] Ballarini A, Basile F, Benito P, Bersani I, Fornasari G, De Miguel S, et al. Platinum supported on alkaline and alkaline earth metal-doped alumina as catalysts for dry reforming and partial oxidation of methane. Appl Catal A Gen 2012;433-434:1-11. http://dx.doi.org/10.1016/j.apcata.2012.04.037.

[15] Sun N, Wen X, Wang F, Wei W, Sun Y. Effect of pore structure on Ni catalyst for CO2 reforming of CH4. Energy Environ Sci 2010;3:366-9. http://dx.doi.org/10.1039/ c003390c.

[16] San José-Alonso D, Illán-Gómez MJ, Román-Martínez MC. K and Sr promoted Co alumina supported catalysts for the $\mathrm{CO} 2$ reforming of methane. Catal Today 2011:176:187-90. http://dx doi.org/10.1016/j.cattod 2010.11.093.

[17] Hou Z, Chen P, Fang H, Zheng X, Yashima T. Production of synthesis gas via methane reforming with $\mathrm{CO} 2$ on noble metals and small amount of noble-(Rh-) promoted Ni catalysts. Int J Hydrogen Energy 2006;31:555-61. http://dx.doi.org/10. 1016/j.ijhydene.2005.06.010.

[18] Rostrup-Nielsen JR. Catalytic steam reforming. Catal Sci Technol 1984;5:1-117. http://dx.doi.org/10.1007/978-3-642-93247-2_1.

[19] Figueiredo JL, Trimm DL Gasification of carbon deposits on nickel catalysts. J Catal 1975;40:154-9. http://dx.doi.org/10.1016/0021-9517(75)90241-9.

[20] Feng J, Ding Y, Guo Y, Li X, Li W. Calcination temperature effect on the adsorption and hydrogenated dissociation of $\mathrm{CO} 2$ over the $\mathrm{NiO} / \mathrm{MgO}$ catalyst. Fuel 2013;109:110-5. http://dx.doi.org/10.1016/j.fuel.2012.08.028.

[21] Hou Z, Yashima T. Meso-porous $\mathrm{Ni} / \mathrm{Mg} / \mathrm{Al}$ catalysts for methane reforming with CO2. Appl Catal A Gen 2004;261:205-9. http://dx.doi.org/10.1016/j.apcata.2003. 11.002.

[22] $\mathrm{Hu} \mathrm{YH}$, Ruckenstein E. Binary MgO-based solid solution catalysts for methane conversion to syngas. Catal Rev 2002;44:423-53. http://dx.doi.org/10.1081/CR120005742.

[23] Arena F, Frusteri F, Parmaliana A, Plyasova L, Shmakov N. Effect of calcination on the structure of $\mathrm{Ni} / \mathrm{MgO}$ catalyst: an X-ray diffraction study. J Chem Soc, Faraday Trans 1996;92:469-71.

[24] Sengupta S, Deo G. Modifying alumina with $\mathrm{CaO}$ or $\mathrm{MgO}$ in supported $\mathrm{Ni}$ and $\mathrm{Ni}-\mathrm{Co}$ catalysts and its effect on dry reforming of CH4. J CO2 Util 2015;10:67-77. http:// dx.doi.org/10.1016/j.jcou.2015.04.003.

[25] Siahvashi A, Adesina AA. Synthesis gas production via propane dry (CO2) reforming: influence of potassium promotion on bimetallic Mo-Ni/Al2O3. Catal Today 2013;214:30-41. http://dx.doi.org/10.1016/j.cattod.2012.12.005.

[26] Han SJ, Bang Y, Kwon HJ, Lee HC, Hiremath V, Song IK, et al. Elevated temperature $\mathrm{CO} 2$ capture on nano-structured $\mathrm{MgO}-\mathrm{Al} 2 \mathrm{O} 3$ aerogel: effect of $\mathrm{Mg} / \mathrm{Al}$ molar ratio. Chem Eng J 2014;242:357-63. http://dx.doi.org/10.1016/j.cej.2013.12.092.

[27] Navajas A, Campo I, Arzamendi G, Hernandez WY, Bobadilla LF, Centeno MA, et al. Synthesis of biodiesel from the methanolysis of sunflower oil using PURAL Mg-Al hydrotalcites as catalyst precursors. Appl Catal B Environ 2010;100:299-309. http://dx.doi.org/10.1016/j.apcatb.2010.08.006.

[28] Montanari T, Castoldi L, Lietti L, Busca G. Basic catalysis and catalysis assisted by basicity: FT-IR and TPD characterization of potassium-doped alumina. Appl Catal A Gen 2011;400:61-9. http://dx.doi.org/10.1016/j.apcata.2011.04.016.

[29] Wang C, Sun N, Zhao N, Wei W, Zhang J, Zhao T, et al. The properties of individual carbon residuals and their influence on the deactivation of Ni-CaO-ZrO2 catalysts in CH4 dry reforming. ChemCatChem 2014;6:640-8. http://dx.doi.org/10.1002/cctc. 201300754.

[30] Wei Z, Karim AM, Li Y, King DL, Wang Y. Elucidation of the roles of Re in steam reforming of glycerol over Pt-Re/C catalysts. J Catal 2015;322:49-59. http://dx. doi.org/10.1016/j.jcat.2014.11.006.

[31] Rêgo de Vasconcelos B, Tran ND, Pham Minh D, Nzihou A, Sharrock P. Synthesis of carbon nanotubes/hydroxyapatite composites using catalytic methane cracking. Compos Interfaces 2015;22:673-87. http://dx.doi.org/10.1080/09276440.2015. 1060055.

[32] Ay H, Üner D. Dry reforming of methane over CeO2 supported Ni, Co and Ni-Co catalysts. Appl Catal B Environ 2015;179:128-38. http://dx.doi.org/10.1016/j. apcatb.2015.05.013.

[33] Wang C, Sun N, Zhao N, Wei W, Sun Y, Sun C, et al. Coking and deactivation of a mesoporous Ni-CaO-ZrO2 catalyst in dry reforming of methane: a study under different feeding compositions. Fuel 2015;143:527-35. http://dx.doi.org/10.1016/ j.fuel.2014.11.097.

[34] Zhang ZL, Verykios XE. Carbon dioxide reforming of methane to synthesis gas over supported Ni catalysts. Catal Today 1994;21:589-95. http://dx.doi.org/10.1016/ 0920-5861(94)80183-5.

[35] Wang N, Shen K, Huang L, Yu X, Qian W, Chu W. Facile route for synthesizing ordered mesoporous Ni-Ce-Al oxide materials and their catalytic performance for methane dry reforming to hydrogen and syngas. ACS Catal 2013;3:1638-51. http:// dx.doi.org/10.1021/cs4003113. 